\title{
A Seeping Commodification: The Long Revolution in the Proliferation of Communication Commodities
}

\author{
Jernej A. Prodnik \\ Social Communication Research Center, Faculty of Social Sciences, Ljubljana, Slovenia, \\ jernej.amon-prodnik@fdv.uni-lj.si
}

\begin{abstract}
The main goal of this paper is to conceptualize a seeping commodification. The author of the paper claims we are in the midst of a considerable qualitative transformation in the processes of commodification that is, in large part, owed to an overwhelming capitalist enclosure of the wider communicative field. The key reason for what seems to be an important qualitative transformation in the commodification process lies in the fact that communication and information flows today run through most social relations and spheres - which non-critical approaches often explain with the concept of the 'mediatization of society'. A materialist approach, distinctive of (critical) political economy of communication, enables an apt critique of these processes. In an epoch, in which capital has enclosed the wider field of communication, mediatization is in fact nothing else than a continuing commodification of our everyday lives. The author of the paper claims that commodification of communication and informational resources must be seen as a long-term process, which has accompanied the rise of capitalism. A considerable proliferation of the economic importance of communication, information, and culture has - to be precise - been enhanced in a large part by political interventions occurring in the last decades (which were a response to the economic tendencies and crises of the time). While the immediate results are observable especially in the proliferation of the new information and communication technologies and the global role of intellectual property rights, the wider social consequences of these developments have been much broader and more influential. This study proceeds from the perspective of historical materialism and adopts dialectics in an attempt to grasp contradictory social changes. The analysis is done through different methods of historicizing: firstly, by observing long-term changes in communication, information, and culture, as they have been slowly transformed into commodities produced for market exchange since the emergence of capitalism; and, secondly, by defining fundamental political and economic processes occurring in recent decades that help with an explanation of the rise in the influence of communication and information (as peculiar types of commodities) in the current epoch.
\end{abstract}

Keywords: Commodification, Information Society, Enclosures, Capitalism, Intellectual Property Rights, Mediatization, Critical Media and Communications History, Political Economy of Communication, Critical Communication Studies.

\section{Introduction}

"It is a tendency of informational flows to spill over from whatever network they are circulating in and hence to escape the narrowness of the channel and to open up to a larger milieu." Tiziana Terranova $(2004,2)$

The main goal of this paper is to conceptualize a seeping commodification ${ }^{1}$. This will be done by providing a necessarily unfinished account of the key mechanisms that have contributed to an increasing commodification of our daily lives, social reality, and both tangible and nontangible resources, things, and relations. This transformation was observed and labelled us-

\footnotetext{
${ }^{1}$ I have presented draft versions of this paper at the IAMCR Conference 2013 in Dublin (Ireland) and at ESA 2013 in Torino (Italy). I have benefited from many constructive comments and critical remarks that I received at these events, but also elsewhere. I would especially like to thank Aphra Kerr for a careful reading of the early version of this text and for her constructive suggestions. I would also like to thank Christian Fuchs and anonymous reviewers for their very helpful remarks that helped me to improve the article.
} 
ing a variety of terms and concepts by authors of diverging approaches and normative presuppositions. Even with all the differences between the authors tackling this issue it seems, however, that there is an increasing agreement about its increasing significance even in the mainstream social sciences.

It will be claimed through this paper we are witnessing a qualitative transformation in the commodification processes that is, in large part, owed to an overwhelming capitalist enclosure of the wider communicative field, which accompanied its increased economic importance. Even though commodification of communicative and informational resources must be seen as a long revolution, to use Williams's (1961/2011) term, these processes have been considerably enhanced by political interventions occurring in the wider field of communication(s) in the last decades. The immediate results of this transformation are observable especially in the development of the new information and communication technologies (ICTs) and the global implementation of intellectual property rights (IPRs), which significantly contributed to the rise of media and cultural conglomerates; the wider (indirect) social consequences of these processes have, however, been far more important and brought about vast social changes, influencing transformation both in the commodification process and in the current capitalist mode of accumulation.

The key reason for what seems to be an important qualitative transformation in the ways in which commodification is now being carried out lies in the fact that communication and information flows inevitably run through most social relations and spheres, persistently breaking apart any solid boundaries. This is done in a manner similar to Marx and Engels's (1848) pertinent observation, when they wrote that "all that is solid melts into air" (where they were referring to a constantly present need in capitalism to revolutionise the means of production, which influenced all other social forms as well). Commodification of communication, as it is claimed in this paper, seems to be leading to a seeping commodification: a historically novel type of commodification, which is able to trickle down into the seemingly insignificant parts of our lives and into the microcosms of social practices and relations. We can thus paraphrase Marx's and Engels's famous sentence into "all that is solid melts into a commodity".

The process of commodification often very directly influences the immediate experiences of individuals on the subjective and inter-subjective level, while it also has a strong influence on the wider society and relations within it ${ }^{2}$. Expansion of the commodity form always produces an observable transformation of our social reality and by a rule makes possible a further increase in economic inequality. It radically transforms social bonds and values that were not based on the market exchange (Thompson 1991, ch.4, ch.5; Harvey 2009, 55-56, 62-64; Wittel 2013, 314) and also necessarily contributes to an enhanced individualization of (and within) society. At the same time, market operates independently and beyond direct control of human beings (Barbalet 1983, 89-92). One of the key points made by Marx $(1976 / 1990,163-177)$ in his theory of commodity fetishism is not only that commodities take on a life of their own, beyond the immediate control of human beings, but that they also claim mastery over people (see also Prodnik 2012a, 283-284). As summed up by Harvey (2010, 42), "market forces, which none of us individually control, regulate us".

This study proceeds from the perspective of historical materialism and adopts dialectics in an attempt to grasp contradictory social changes. The analysis is done through different methods of historicizing: firstly, through the Braudelian longue durée approach (Braudel 1980), which is used to analyse the long-term changes in communication, information, and culture, as they have been slowly transformed into commodities produced for market exchange since the fifteenth century; and, secondly, by defining fundamental political and economic processes occurring in recent decades that help with an explanation of the rise in the influence of communication and information in the current historical epoch. As it will be claimed through this paper, the incentives for these changes were primarily political (and went beyond purely national policymaking); but they should, at the same time, be seen as a definitive response to the economic tendencies, conflicts, and necessities of the time.

\footnotetext{
${ }^{2}$ For an overview see Prodnik (2012a).
} 
In this paper, I first describe how there is an increasing awareness about the commodifying tendencies that are ever-present in capitalism (Section 2). Authors however often use euphemisms in describing these processes in society. I claim political economy of communication has been more precise in talking about commodification and commodity-form, connecting these two concepts to the capitalist production. In the next section (Section 3), I identify historical dialectical approach as the only possible way of making sense of the on-going contradictory social transformation (it manifests itself simultaneously as continuity and discontinuity). In the mentioned section I also emphasise how there is an increasing importance of information, communication, and culture in the existing historical phase of capitalism. In the following section (Section 4), I analyse commodification of communication and information in a deeply historical manner, looking at how these resources have been subjugated to capitalist market relations since the capitalist economic system first emerged several centuries ago. Their commodification therefore was part-and-parcel of the developing capitalism, accompanied by recurring conflicts, contradictions, and antagonistic struggles. Next, I explain how it was especially political incentives and interventions (policymaking, funding, etc.) that led to the increasing social, economic and political significance of the information and communication systems and resources we are witnessing in the last few decades (Section 5). In the section that follows (Section 6), I note we are witnessing new enclosures via recurrent processes of primary accumulation, which make possible incorporation of different spheres under capital. This brought about a possibility for a further expansion and intensification of commodification throughout society. In the last part of the text (Section 7) I build on the preceding sections and conceptualize a seeping commodification as a historically novel type of commodification, which trickles throughout society.

\section{The Universalization of the Commodity Form}

"They know the price of everything and the value of nothing."

Oscar Wilde

The history of capitalism has, amongst other things, also been a history of a never-ending (global) commodification. Nowadays, issues connected to these sustained processes are not limited to the supposedly radical margins of social sciences as they were in the past. Awareness of the on-going transformation became important both in the more popular media discourse and in mainstream academic research. According to Wittel:

There seems to be a broad consensus that commodification is a fact, the capitalist market has become increasingly powerful, pervasive and hegemonic, the logic of the capitalist market colonises and destroys the logic of community, and that the market swallows more and more areas and aspects of life that hitherto have not been regulated by monetary measurement and monetary exchange (Wittel 2013, 315)

However, the term commodification has, in many of these analyses, been replaced by euphemisms such as financialization, marketization, monetization, or simply "the reign of money". Martin (2002), for example, deployed the concept of the financialization of everyday life, claiming that money has become both the means and the final goal of human lives. Because financialization broke beyond the corporate world into the households of the ordinary people, this forces them continuously to act and think like capitalists, even though they have little to no capital (Martin 2002, 12). Simultaneously, they are accepting risk (formerly dealt with by professionals) into their homes and into their everyday activities. The lives of many people, claimed Martin $(2002,5)$, are becoming an endless business school course, and every possible moment consequently needs to be turned into an opportunity to make money.

Martin is not alone in his observations. Sandel (2012) has recently posited very similar questions. Seemingly endless expansion of market relations prompts him to ask the ques- 
tion, "What money can't buy?". Leaving capitalism to its own expansionary logic, any strict limits to its penetrating abilities seem illusory. It seems Sandel agrees with this notion. Economics "is becoming an imperial domain", because it "increasingly governs the whole of life" (Sandel 2012, 6), he laments. This is because "almost everything can be bought and sold," and markets "have come to govern our lives as never before" (Sandel 2012, 5).

What seems equally important to the findings is the fact that both Martin and Sandel say these new "marketized" relations were not arrived at by any conscious or autonomous decision of the people that succumbed to it. These conditions in fact slowly but surely became a part of individuals' lives and encroached upon their everyday activities without any visible coercion. What would never be considered self-evident a couple of decades ago, today seems almost beyond dispute, an unquestionable imperative of human agency fully subjected to market forces. Because of an overwhelming intensification of social commodification, rationalistic calculation and measurement have become part and parcel of human activities and relations, while exchange-value equivalence and factual abstraction have simultaneously become the norm for many individuals in their everyday operations (see Prodnik 2012a) ${ }^{3}$.

Critical communication and social studies have, in fact, long been aware of this social transformation. Herbert Schiller (1984, xiv) observed almost three decades ago that "the penetration of corporate power and corporate thinking is now so extensive that the calculus of business performance has become the almost automatic measurement of individual purpose and achievement". In Marxist and other radical political-economic approaches including those in the field of critical communication studies (e.g. Murdock 2006a; Mosco 1989; 2009, ch.7; D. Schiller 2007; Prodnik 2012a; Fuchs 2014, 52-53) - these processes have fallen under the umbrella of theories that analyse the role of the commodity form and commodification in capitalist societies ${ }^{4}$.

The concept of commodification, contrary to the commonly used euphemisms mentioned earlier, necessarily looks beyond appearances, into the structural causes of the existing capitalist relations in wider society, which makes it a more extensive concept (Mosco 2009, ch.7; Prodnik 2012a). Commodity form is one of the cell forms of capitalism, as Marx (1976/1990, 90) put it, and only in capitalism is a "collection of commodities" considered an "elementary form of wealth" (Heinrich 2012, 39-41). Commodification of diverse social processes and spheres, which enables an endless global accumulation of capital, is consequently the defining characteristic of historical capitalism: it enables its further expansion and reproduction (Wallerstein 1983, ch.1). At the same time, one should not overlook that one of the defining characteristics of the commodity form is that it is necessarily produced in the capitalist production process, which necessarily puts focus on the (un)waged labouring processes, the relations of production, and exploitative practices (Marx 1976/1990). Furthermore, commodities are necessarily produced for the market and exchanged on the market in the capitalist production (D. Schiller 2007, 21). Expansion of commodification has now extended work and exploitation beyond the factory floors and into the other spheres of human lives (Smythe

\footnotetext{
${ }^{3}$ Livant's $(1979,105)$ lucid observation speaks volumes in this case. He points out that "the main impetus to the rise of measurement is the rise of commodity production. Where something begins to be measured it is an almost sure sign it is being traded."

4 Both Bettig $(1996,34)$ and Gandy (1992) write about radical political economy of communication, which is a similar differentiation to the one that is made by Winseck in his own typology (see: Winseck 2011, 21-25). While it is mostly Marxist approaches that fall under the umbrella of radical and critical political-economic approaches, some authors are not using an explicitly Marxian theoretical framework, but can nevertheless be considered as critical scholars, because they reflect on the social inequalities and provide a critique of the capitalism, adopt a deeply historical perspective, use dialectics to discern key structural developments in the society, while at the normative level they argue for a better and more equitable world that could fulfil human potentials. Such authors were either influenced somehow by Marxist thinking, see themselves as neo-Marxists, or adopt a theoretic framework that is similar to the one used by Marx. The most obvious example is perhaps Herbert I. Schiller, who was not explicitly a Marxist because of practical reasons (namely McCarthyism and other anti-communist witchhunts), but also took his inspiration from other approaches (Maxwell [2003, 4] for example writes about "radical eclecticism") (see: Maxwell 2003; Murdock 2006b). Fuchs (2014, 52-53) provides a somewhat more strict definition of the approaches that can be defined as being critical. In his opinion there were two main schools that provided a critical insight to the media, communication and culture: Critical Political Economy of the Media and Critical Theory, first one being rooted in economic theory, and the second one in philosophy and social theory.
} 
1977; Terranova 2004; Marazzi 2008; Fuchs 2012a; Crary 2013; Fuchs and Sevignani $2013)^{5}$.

\section{The Dialectics of Social Transformation and the Information Revolution}

"The mark of some successful dialectic is shock, surprise, and the undermining of preconceived notions."

Fredric Jameson $(2003,196)$

Historical accounts tracing the emergence of culture, information, and communication as somehow relevant parts of capitalist production and accumulation (the material base) usually extend only as far back as the second half of the twentieth century. In this historical period, there was supposedly a radical socioeconomic transformation, a clean break with the past that brought about the information society, which would abolish the antagonistic class relations and thoroughly alter the labour-capital relationship. Theories that developed the notion of an information society and a post-industrial society pointed at several mechanisms that contributed to this radical historical break, but the sharply increasing social and, especially, economic importance of the information resources was, in all likelihood, crucial. This was the so-called information revolution, which supposedly resulted from the new ICTs ${ }^{6}$.

Significantly, this historical period, as Herbert Schiller $(1973,13)$ pointed out at the time, was in fact "one of the most spectacular decades of social conflict and manipulative control in the United States' history". The end of the 1960s and the beginning of the following decade saw an almost worldwide rise of the New Left, persistent student protests, and new social movements that brought to the fore new political issues and conflicts (Offe 1987). These perturbations can, at least to an extent, also be seen in the light of the on-going process of decolonization that exposed serious worldwide inequalities and continuing dependencies of the nations that were now formally independent, these dependencies being implemented through both cultural imperialism and neo-imperialist practices (H. Schiller 1969; 1976; Harvey 2003, chapter 2; Thussu 2006, 24-37, 46-55). Cultural imperialism and cultural dependency were not a question of conspiracy or manipulation, but a structural fact according to Mattelart $(2000,67)$, main reason being unequal information and communication exchange on a worldscale.

It was this antagonistic social context that made Bell's proclamations of the "end of ideology" even more incomprehensible (or, perhaps, revealed it to be wishful thinking). What today seems plausible is that the primary (even if implicit and unintentional) consequence of the information society theories was to legitimize a comprehensive political-economic and wider societal reorganisation, which would provide a new social stability in the time of political perturbations and looming systemic economic crisis, as the existing mode of capitalist accumulation process reached its limits (Offe 1985). Critical authors, after all, promptly demystified key presuppositions contained in these theories and successfully demonstrated that societies will remain deeply embedded in the inequalities and asymmetries that are distinctive of capitalism, even if information resources are in fact gaining in importance (DyerWitheford 1999, 77; cf. Dupuy 1980; Splichal 1981; Mosco 1982; 1989). Several authors today agree that the last few decades have, in fact, brought about a consolidation of capitalism and a deepening of commodification, consequently increasing economic inequalities and prompting new antagonistic conflicts between capital and labour?

\footnotetext{
${ }^{5}$ Several authors have extensively written on this topic (see also Prodnik 2012a). In Marazzi's (2008, 50) opinion "today the capitalist organization of work aims to overcome this separation, to fuse work and worker, to put to work the entire lives of workers." Crary (2013) has similarly pointed out there is a 24/7 logic in contemporary capitalism: non-stop consumption, exploitation, and commodification, an idea of constant work without any pauses or limits, spreading throughout society.

${ }^{6}$ For a critical account see for example Mosco (1989), May (2002), D. Schiller (2007, ch.1), Fuchs (2012b).

7 See Dyer-Witheford (1999), May (2002, ch.2), Mosco (1989; 2009, 75, 120), McChesney, Wood and Bellamy Foster (1998), D. Schiller (1999; 2007), Fisher (2010), Fuchs (2008; 2011; 2012b) and other authors writing in the broad field of political economy of communication.
} 
Looking at the surface of things, it therefore seems that we are confronted with a considerable contradiction. On the one hand, we are forced to acknowledge that, in the past few decades, there has indeed been an important reconstruction, not only of the existing mode of capitalist production and accumulation (new one often being labelled as post-Fordist), but also of the wider social fabric and of our everyday lives. This change is in large part owed to the increasing role played by information resources, communication, and knowledge, all of which have gained in economic importance. Mosco (1982; 1989), for example, was in the 1980 s already debunking fantasies about the radically different social order that had supposedly originated from the changes brought by the new ICTs. However, at the same time, he also indicated that information had indeed become "vital to corporate capital accumulation" (Mosco 1982, 46). Similarly, Dan Schiller $(2007,24)$, another author who is very critical of the information society theories, points out that "[o]ften supported by telecommunications infrastructures, information has become an increasingly significant factor of production across all economic sectors".

The insights that would simultaneously theorize both social continuity and discontinuity seem in stark opposition to the popular discourse, in which everything has changed in the last decades because of the rise of the new technologies, and also to some of the more orthodox authors in the field of critical political economy who even today often claim there was no relevant change at all in society and in how capitalism operates in the present historical phase $^{8}$. Eran Fisher (2010) analysed the celebratory discourse connected to the network technologies and new ICTs and called it the digital discourse, pointing out that the spirit of networks embedded in it is dominant in academia, political and economic circles and especially in the popular jargon (he analysed the hyper-celebratory discourse of the Wired magazine) (cf. Mosco 2009). This hyper-optimistic discourse can be contrasted with a diametrically opposite one, which is, for example, present in Doogan's (2009) work. He provides a critique of what he terms the new capitalism on "the ideological, methodological and empirical basis of the societal transformation" (Doogan 2009, 4). While one can agree with his main argument that there is a need to provide a critique of the theories of radical discontinuity, for Doogan even using concepts such as knowledge, informationalism or networks is "nebulous", because they are "difficult to pin down and [are] resistant to close scrutiny, while globalization is a term whose usage is perhaps inversely proportional to the precision of its meaning." (Doogan 2009, 5) It seems that for Doogan every theory which even suggests there was any relevant social change "rests upon an idealized representation of contemporary society." (Doogan 2009, 6) It is "devoid of the materialist iconography," (Doogan 2009) and this holds true whether one is reading insights by Harvey, Bell, Castells, Beck, Bauman, Boltanski and Chiapello, or Sennett; their theories are all the same in the way they privilege discontinuity and "over determine the role of technological change". In Doogan's $(2009,6)$ view we thus need to "rematerialize an understanding of social change."

Such a generalizing and overarching assessment of even those approaches that are very critical in analysing the present social changes seems far-fetched and (indeed) nebulous. However, even if we concede that there were important changes in capitalist accumulation, we must also inevitably recognize that the system in its essence has remained capitalist. There was consequently no drastic change in the basic political economic organization of the social order - unlike what affirmative apologists claimed would happen - a conclusion most authors writing in the field of political economy of communication were (and still are) in full agreement. The changes in the new technologies therefore brought about a deepening, expansion, and acceleration of the capitalist accumulation and commodification on the one hand, and an intensification of control on the other, and not some kind of social revolution (Mosco 1989, 34-35).

\footnotetext{
${ }^{8}$ Fuchs $(2012 b, 2-6)$ provides a detailed critical assessment of the discontinuity and continuity theories of information society. As he points out: "In its extreme form, the continuity hypothesis is the claim that contemporary society does not differ in any significant way from nineteenth-century capitalism" (Fuchs 2012, 6) Both discontinuity and continuity approaches are intellectually close to techno-deterministic theories that disregard the everpresent power relations in specific social context.
} 
One possible way of resolving this apparent contradiction between social continuity and discontinuity is by adopting the historical method of thinking from critical theory. We must radically historicize the key categories we are investigating, demonstrating that they are historically transitive and malleable. As Bonefeld $(2009,125)$ would have put it, echoing Marx and Engels, "historical materialism is the critique of things understood as dogmatic. It melts and dissolves all that appears solid". Furthermore, we must also turn to dialectics, which will help us to (re)think these internal contradictions related to the complex mutual relationship between social change and continuity. Fredric Jameson (1998, 171; cf. Marx 1973/1990, 103) pointed out that it enables us to simultaneously think two faces of history "which we otherwise seem ill-equipped to think: namely identity and difference all at once, the way in which a thing can both change and remain the same, can undergo the most astonishing mutations and expansions and still constitute the operation of some basic and persistent structure."

Fuchs (2012b; cf. 2014, 53-55) has in a way similar to Jameson's account of dialectics used Adorno's dialectical approach for his critique of both the approaches that see societal changes in the terms of radical discontinuity on the one hand, and on the other hand those that see no changes at all (theories of radical continuity). As Fuchs points out we live both in capitalism and in an informational society: "In terms of critical, dialectical theory, contemporary society is an information society according to the state of its forces of production. In contrast, however, contemporary society is capitalist in its relations of production" (Fuchs 2012b, $18 ; 2014,55)$ A similar distinction was made earlier by Douglas and Guback (1984) and by May $(2002,42-43)$. They all pointed out that even if one can talk about a technological revolution (in the forces of production), the relations of production could not only remain the same, but could in fact be consolidated even further. But as Fuchs $(2012 b, 16)$ furthermore notes, even if informational character of global companies is increasing in importance, it remains "a non-dominant trend", as both finance and fossil fuels for example remain more important. It is thus, in his opinion (Fuchs 2012b, 16), "financialization, hyperindustrialization, and informatization [that] characterize contemporary imperialist capitalism."

By adopting a materialist perspective, the concept of the so-called information revolution must therefore be connected to the increased social need for information in the current historical epoch. A key characteristic that has accompanied this emerging social need in the last few decades - which was, in its essence, a result of the existing social relations of power - is that information and communication have finally and completely constituted themselves as commodities that are bought and sold on the market. Two decades ago, Melody (1993, 75; cf. Hesmondhalgh 2008, 97) pointed out how "information that previously was outside the marked and not included as economic activity has now been drawn into the market". In May's $(2002,129)$ view, similarly, the age of information therefore "does not change the character of capitalism", it does however "require the renewal of certain aspects of property law, most importantly the reconfiguring of intellectual property rights. The information age has prompted the extension of intellectual property into areas previously unavailable for commodification" (cf. also May 2010). New ICTs that were developed and also made possible this technological infrastructure can be seen as influential, but by no means determining factors, contributing to the social changes as information is produced, processed, and transmitted through these new communication channels.

It is, however, a historical fact that commodification of communication, information, and culture commenced long before the emergence of the so-called post-industrial/information society and also long before the constitution of the heavily enlarged cultural industries. Information has therefore for a long time been produced for the capitalist market, but never to such an extent as in the current historical context. Alas, even if communication and information have now fully constituted themselves as key commodities inside the capitalist accumulation process and the capitalist market, neither their social influence nor commodification started with the rise of the information society, as ideologically biased ahistorical theories claim. (see Headrick 2000; D. Schiller 2007) 


\title{
4. Commodifying Communication and Information in the Longue Durée
}

\author{
"Each 'current event' brings together movements of different ori- \\ gins, of a different rhythm: today's time dates from yesterday, \\ the day before yesterday, and all former times."
}

Fernand Braudel $(1980,34)$

Human societies have always been based on both communication and information. Language-capacity and communication can, in fact, be seen as defining characteristics of human societies. Hardt $(1976,19)$ points out that communication is "a basic social process involving individuals. In fact, communication becomes the sine qua non of human existence and the growth of society". Similarly for Mosco $(2009,67)$, "communication is a social process of exchange, whose product is the mark or embodiment of a social relationship. Broadly speaking, communication and society are mutually constituted". As noted by Melody (1993, 75), "detailed investigation certainly would show that societies have always been information based," which consequently means that "the changes of recent years have been primarily in the market characteristics of information".

Because both communication and information have always been fundamental parts of human societies, Headrick (2000, ch.1) wrote it is consequently also impossible to define when the information society in fact started. We are, however, able to define different historical epochs in which the wider importance of information in a certain social context has been intensified, both in the sense of the amount of information to which people have access, and in the sense of the changes in the information systems that are crucial for the management, organization, transformation, and storing of information. At most it is therefore possible to define several information revolutions according to Headrick (2000), not only one that supposedly started in the middle of the twentieth century. These revolutions have always been put in motion by cultural, political, and economic upheavals of the times and were closely connected to existing social needs; undoubtedly they were responses to the demands for information (and their overall organization), echoing the wider power relations in societies.

The so-called information revolution we have been witnessing in recent decades should, therefore, only be seen as a long revolution, as Williams (1961/2011) named the long-term processes of transformation. The changes he analysed were happening in different spheres of culture, politics and economy, and in his view could not be considered as being separate from each other, as they dialectically intertwined. For Williams $(1961 / 2011,10)$ long revolution should be considered as "a genuine revolution, transforming men and institutions", yet it is at the same time "a difficult revolution to define, and its uneven action is taking place over so long a period that it is almost impossible not to get lost in its exceptionally complicated process" (Williams 1961/2011,10). The changes that accompanied the not-so-recent rise in the importance of communication, culture and information resources, points at a similar longterm change, one that developed as a part of an ever-changing capitalist economic system, while simultaneously overlapping with contradictory and deep structural transformation in the wider social order.

The latest information revolution can, according to Headrick (2000, ch.7), quite possibly be traced back several centuries into the past, or at least to the second part of the nineteenth century, if we follow Winseck's and Pike's (2007) analysis. They point out how this was the historical period when global communications infrastructure was developed and first utilized, mostly owing to the emergence of deep globalization: that is, the expansion of the world markets, the rise of multinational companies and financial institutions, and the intensification of capital flows and global commodity exchange. At the time, global communication infrastructure was closely connected to these globalizing tendencies, including the development of new technologies. International commodity exchange and the increasingly global division of labour propelled the need for fast international communication, as successfully overcoming time-space constraints was often of fundamental importance (because it could also mean an important competitive advantage in the market). These tendencies had already been not- 
ed by Marx (see Melody 1993, 68-70; Dyer-Witheford 1999, 38-42; Fuchs 2011, 141-160) and were especially closely observed by another German political economist, Knies, who wrote detailed analyses of communications and transportation systems, including two monographs, addressing, respectively, railroads and the telegraph, which were both published in the 1850s (see Hardt 2001, chapter 4).

The close connection between communications infrastructure, information and communication flows, media and culture, and the underlying economic transformation was closely observed by several other authors long before the formal emergence of communication studies in the twentieth century. In his historical analysis of journalism, Bücher (1893/1901, 241), one of the founding fathers of the German Zeitungswissenschaft, for example, pointed out that the "sole aim of this cursory survey of the modern development of journalism" was "to show how the gathering of the news has been conditioned at each epoch by general conditions of trade". His materialist and historical approach to the analysis of newspaper even today provides us with several important insights ${ }^{9}$. Bücher (Ibid, 225-226) was, in fact, one of the first authors to demonstrate that news-agencies and journalism first developed as businesses in Venice and Rome in the fifteenth century. This would mark the starting point of the historical period when transmission of the news via commercial correspondence became a source of profit. As historians in the field of media and communication studies have indicated, Venice was in fact the first city in Europe in which printing and publishing became an important type of business, and this development also included laws regulating the printing and publishing trade, which can be considered as precursors to the copyright system (Bettig 1996, 15-16). Even more importantly, it is crucial to note that the emergence of a news-forprofit rationale historically and spatially overlapped with Arrighi (1994) and Braudel's (1977) accounts of the historical rise of capital. According to their analyses, the "first great phase" of capitalism as a social system started in the northern Italian city-states around the fifteenth century, and this included Venice as one of the key financial centres of the time.

As pointed out by Dan Schiller (2007, 35), "[c]ultural and informational commodification commenced not after, but within, the acute social struggles marking the transition to capitalism". These processes were, therefore, a part and parcel of structural changes and social struggles that accompanied the social transformation into capitalism (Smythe 1954, 31-34; H. Schiller 1996, 35; Hardt 2001, chapter 1; D. Schiller 2007, 34-35). But these developments were neither self-evident nor indispensable; in many cases, they were accompanied by social conflicts and opposition, and were actively countered by more or less unsuccessful uprisings against the capitalist enclosure. Williams (1961/2011, 191), for example, noted that there were already several publishing houses in England in the sixteenth century, however commodity exchange of books was still considered vulgar at that time and there was consequently significant resistance against the publishing market.

The emergence of modern IPRs was, at least from today's point of view, one of the more important changes, with vast (and unplanned) consequences that we are still in the process of fully comprehending. In their historical analyses of the gradual transformation of information and culture into a special type of commodity, both Dan Schiller (2007) and Bettig (1996, 22-23) have pinpointed the eighteenth century as a crucial historical moment, when legal regulation of IPRs first appeared in England (cf. Hesmondhalgh 2009, chapter 5). Because these rights spread to human creativity, they also enabled its commodification. But, even before that, at the end of the seventeenth century, there was a considerable growth in the size of the reading public, which dialectically contributed to an expansion of the production and circulation of newspapers, books, magazines, and, consequently, also constituted a considerable expansion in the commodification of information and media (Williams 1961/2011, 192-193; Headrick 2000, chapter 1). The newspaper is, for example, often considered to be a product of the commercial middle class in the eighteenth century, since it provided them with crucial business information essential for their activities (Williams

\footnotetext{
${ }^{9}$ Bücher was not a Marxist and his approach cannot be defined as historically materialist in the Marxian use of this term. His analysis however was both deeply historical and also materialist in the sense of a long-standing philosophical split between idealist and materialist approaches to the social ontology (see for example Hay 2002, chapter 6).
} 
1961/2011, 208, 222; Mosco 1989, 50). Because these early newspapers were still limited to a relatively narrow circle of people, a real reading revolution in England, which was followed by a vast market expansion of the press, only happened in the nineteenth century, especially between 1830 and 1850, when the first market speculators emerged. Writing became an important part of commodity exchange in England at that time and also led to a transformation of the media and press into typical capitalist industries; a process that was fully consolidated only at the start of the twentieth century (see Williams 1961/2011, 200; 1962).

A very similar historical development of the press to that which occurred in England could be observed in most developed capitalist countries, for example, in the US, where business imperatives in the media prevailed in the nineteenth century; this meant that both news and, later, advertising space, became important commodities (Schudson 1978). At around the same time, the first modern press agencies were founded around the world (Thussu 2006, 910) and there were also vast changes in postal services and telecommunications throughout the nineteenth century, which provided infrastructure for the distribution of communication and information as commodities (see Headrick 2000, chapter 6; Pike and Winseck 2007). According to Mattelart $(2000,23-24)$ it was exactly the rise of the major European news agencies and their international orientation throughout the 1870 s that ultimately marked the rise of the market in information on a global scale ${ }^{10}$.

Hesmondhalgh $(2007,57)$ distinguished between three stages in which texts have been commodified: The first stage occurred in the fifteenth century and was connected to the commodification of tangible objects, such as books; the second stage has been occurring from the eighteenth century onwards with the emergence of IPRs and is connected to the information contained within tangible object as "the work"; the third stage, which we are currently witnessing and which first emerged with the late twentieth century, is commodification of the access to the information (e.g. via electronic databases). Commodification of access prompted Mosco (1989) to write about Pay-Per Society, whereas Rifkin (2000) labelled the present historical context as the age of access. As one can see, further restrictions to access and its commodification intensified, when the importance of intangible goods as such increased; this mainly happened because it became easier to reproduce them, which became particularly evident with digitalization.

Authors writing about the rise of the so-called information society in most cases have failed to grasp this longer historical genealogy because of the implicit technological determinism that was a part of their theories (Dyer-Witheford 1999; D. Schiller 2007). Because of historical ignorance, they failed to notice that information resources had been subject to capitalist economic relations much earlier. What was happening throughout the twentieth century was, in fact, a long-term and continuous expansion of commodification in this field, which was closely connected to the development of capitalism.

\begin{abstract}
Against those accounts that see the information society in terms of technological revolution, it is also important to emphasise that the appropriation of information and information resources has always been a constitutive aspect of capitalist societies quite outside of any technological context. [...] The gathering, recording, aggregation, and exploitation of information can be - and has been-achieved on the basis of minimal technological support (Robins and Webster 2004, 63).
\end{abstract}

Instead of directing our focus on the rise of the new ICTs as the main incentive that supposedly produced changes in society, we are therefore bound to point to the diverging and changing types of access to the management and control of information (Robins and Webster 2004), which nowadays are mainly dependent on financial considerations and are going through new enclosures. These continuing changes have established new economic - and with them social - inequalities; for example an unequal access to formerly public information

\footnotetext{
${ }^{10}$ At the time three major European news agencies - German Wolff, British Reuters, and French Havas - were also the only agencies that were international in their scope. They made a cartel pact (treaty of alliance) in 1870s, through which they divided the world into territories of influence. This cartel lasted for over fifty years. (Mattelart 2000, 23-34)
} 
and culture, information poverty, and an intensification of global dependencies because of the concentration of communication capacity and information is in the hands of the biggest capitalist conglomerates and corporations. ${ }^{11}$ In any case, communication, culture, and information were being produced as commodities centuries ago, but their role in the overall capitalist production and wider accumulation process only slowly became as influential as it is today.

\section{5. “It's politics, stupid!"}

"The information sphere is becoming the pivotal point in the American economy. And, as the uses of information multiply exponentially by virtue of its greatly enhanced refinement and flexibility - through computer processing, storing, retrieving, and transmitting data - information itself becomes a primary item for sale." Herbert I. Schiller (1984, 33, emphasis by author)

Deep globalization was, as already mentioned, one of the important factors contributing to the infrastructural development of global communication systems. However, there were several other causes and processes contributing to the exceptional expansion of the wider field of communication (and, consequently, its commodification within capitalist societies) throughout the nineteenth and the start of the twentieth century. Amongst others were the emergence of the popular press and, later, a vast expansion of the culture and media industries. For Williams $(1961 / 2011,211)$ and Herbert Schiller $(1984,77)$, improvements in the productive and distributive methods that were propelled by industrialization were of considerable importance in these changes. Likewise, one should not overlook the expansion of the basic democratic freedoms that were an important process accompanying the struggle for democratization, connected to the rise of liberalism, liberal democracy, and also urbanization (cf. Williams 1961/2011, 211; Hardt 2001, chapter 1; Jhally 2006, 50). Urban industrialization - which was, in fact, closely linked to the primary (primitive) accumulation and enclosure of the commons (Marx, 1976/1990, part 8; Perelman 2000) - for example, significantly eroded the older (rural) cultural forms, which opened up the space for mass culture, which could now be produced as a commodity (Jhally 2006,50$)$. As Smythe $(1954,34)$ noted over half a century ago, "The mass media now supply entertainment which more than fills the quantitative void left by the displacement of the older rituals for entertainment". There was also an explosion of advertising, which radically changed the economic organization of the press at the start of the twentieth century and greatly contributed to its expansion (see Park 1922, 360365; Williams 1962, ch.2; Baker 1994; Curran 2004, ch.3).

But, even if we take all of these different social processes into consideration, it remains fairly difficult to explain what contributed to such a considerable qualitative change that turned communication, culture, and information as commodities into crucial resources in the existing capitalist mode of production and accumulation, even to the extent that, in some cases, they are now defining other political economic processes in the current historical epoch. North American political economists of communication are in full agreement that the key transformation was in fact led by political incentives and state interventions in this field. Herbert Schiller (1969; 1984; 1998; 2000, 49-54), Dan Schiller (1999; 2007), Michael Perelman (2002), Vincent Mosco (1982; 1989; 1993), Nick Dyer-Witheford (1999) and Christopher May (2002, chapter 5; cf. 2010) are amongst the authors pointing out that the political interventions were in fact the ones that led to what is often labelled as the information society and information revolution.

The increasing social, economic and political significance of information and communication systems and resources (both the infrastructure and the content) was ascertained in the

\footnotetext{
11 See for example Mosco (1989; 1994, 117-120), H. Schiller (1989; 1996), Bettig (1996), Perelman (2002), McChesney (2013). According to Perelman (2003b, 32; cf. 2002) "stronger intellectual property rights contribute to the unequal distribution of income and property, have destructive consequences for science and technology and the university system, inundate society with legal disputes, and reduce personal freedoms through intrusive measures to protect intellectual property".
} 
US in the 1950s and, especially, in the 1960s. Key political administrators and decisionmakers have, together with the biggest corporations and conglomerates, and in co-operation with the military-industrial complex, realized that controlling communication and information resources and infrastructure is of prime importance if the US wants to expand its economic interests beyond their own borders in the areas that were beyond their immediate political control, defining the terms of global hegemony. The goal was not an old-fashioned imperial control through military might and interventions (even though the possibility of this could not be excluded), but was aimed at providing opportunities to the biggest conglomerates and commencing what Harvey (2003, chapter 2 ) called the "capitalist imperialism". At the same time, as Herbert Schiller $(1984,48)$ indicated, development of the information sector was intended to help in the revitalization of capitalism, both nationally and internationally, and to provide a solution to the enduring economic crisis.

It was the key decision-makers, therefore, that acted according to these presuppositions and goals by deploying international policies, enacting different state interventions in the field and providing the industry with huge governmental funding for research and development (R\&D). National and international policies in the wider field of communication became an important part of the neo-imperialist tendencies in American politics and economics, and were coupled with cultural imperialism, which (perhaps often quite unintentionally) spread the vision of the American dream around the globe. They were implemented in the so-called military-industrial-communication complex that was most closely analysed by Herbert Schiller (1969; cf. Maxwell 2003, chapter 2). Schiller had already analysed these tendencies in his first major work, Mass Communications and American Empire (1969), and further developed his analysis in his key work Communication and Cultural Domination (1976) ${ }^{12}$. He pointed out that the imperial expansion of American power could be carried out only in parallel with the expansion of technological and communication "industrial" complexes. They helped to spread the media content and, with it, a very specific ideology, which would help to sustain American hegemony and incorporate new areas into the world capitalist economy. The crucial underlying objective of Washington's international communication policies was therefore "to secure as large a part as possible of the ex-colonial world for the world market system" (H. Schiller 2000, 42).

These imperial intentions helped to build an international system that suited American political and, especially, economic interests in the territories that were formally outside of their immediate control. This is perhaps best exemplified by the free flow of information doctrine that promoted a global free market in media, culture and information resources $(\mathrm{H}$. Schiller 1976, chapter 2). Its political objective was, to put it in the words of Hardt (2004, 53-54), to ease "unrestricted trade, including the flow of cultural goods through channels of mass communication, for purposes of creating favourable social or political conditions of controlling the production of everyday realities". It helped to expand capitalism around the globe and develop markets in non-capitalist territories. The free flow doctrine in turn directly produced new international dependencies, especially in the field of information and communication (see Thussu 1998; 2006). With this intention in mind, "the free flow doctrine has been elevated to the highest level of U.S. foreign policy," Herbert Schiller $(1984,56)$ noted in 1980s (cf. H. Schiller 1969; Mosco 1993; Mattelart 2000, 50; Perelman 2002) ${ }^{13}$. Only a couple of years later the free flow of information doctrine became fully united with its more wide-reaching big brother, the neo-liberal political economic doctrine of a full-blown laissez-faire free market capitalism, which consolidated itself in the 1980s in the US and the UK and since the 1990s spread throughout the globe (cf. Thussu 2005; Hesmondhagh 2008).

The free flow of information doctrine attempted to present commodification and privatization of communication and information resources and their global exchange as natural and beyond-dispute, even though there were manifest struggles against incorporation of these

\footnotetext{
12 These issues remained amongst his major research interests until his death (see H. Schiller 2000).

${ }^{13}$ As Herbert Schiller stressed at the end of the 1990s (see H. Schiller 2000, 76-87), this doctrine remains crucial in governmental documents of the United States together with an imperative of private property (e.g. over information via patents and intellectual property rights) right to this day. Its fundamental principles are enforced through international agreements and different bilateral arrangements between nation states.
} 
fields into the capitalist market. The main intentions of the doctrine were ideologically presented as if the free market commodity exchange is a completely neutral, fair and unbiased exchange between equally powerful actors ${ }^{14}$. In fact it served especially those corporations (and countries helping them) that were already the most powerful on the capitalist market ${ }^{15}$. To put it in the words of Herbert Schiller $(1976,45)$, "when there is an uneven distribution of power," a free hand of the market "serves to strengthen the already-powerful and weaken further the already-frail". In his opinion "freedoms that are formally impressive may be substantively oppressive when they reinforce prevailing inequalities while claiming to be providing generalized opportunity for all" (Schiller 1976, 45). Or as he emphasized years later:

\begin{abstract}
The free flow of information doctrine, undeniably beneficial to the already powerful, is a fraudulent construct. The flow of information it promotes is free in one respect only. The flow is expected to be freely admitted to all the spaces that its providers desire to transmit it to. Otherwise, there is nothing free about the information. Quite the contrary. Information and message flows are already, and continue to be, priced to exact the highest revenues extractable. Recent decades have witnessed the steady transformation of public information into saleable goods. Improved electronic information processing facilitates greatly the ability to package and charge for all kinds of messages and images (H. Schiller 2000, 85)
\end{abstract}

According to Dan Schiller (2007, 39-48), the key role played by political interventions in the rise of the information and communication commodities and systems can be recognized in several different areas, including: 1) Funding research and development in telecommunications; 2) "Liberalization" of the communication market; 3) Changing global trade and investment regulations to favour services; 4) Privatization of formerly public and freely accessible information; and 5) Strengthening legal rights to private property in information. Most of the

\footnotetext{
${ }^{14}$ Like it is the comprehended in the liberal theories; to put it in the words of Marx (1976/1990, 280), commodity exchange in the sphere of circulation "is in fact a very Eden of the innate rights of man. It is the exclusive realm of Freedom, Equality, Property and Bentham. Freedom, because both buyer and seller of a commodity, let us say of labour-power, are determined only by their own free will. They contract as free persons, who are equal before the law. Their contract is the final result in which their joint will finds a common legal expression. Equality, because each enters into relation with the other, as with a simple owner of commodities, and they exchange equivalent for equivalent. Property, because each disposes only of what is his own. And Bentham, because each looks only to his own advantage. The only force bringing them together, and putting them into relation with each other, is the selfishness, the gain and the private interest of each. Each pays heed to himself only, and no one worries about the others. And precisely for that reason, either in accordance with the pre-established harmony of thing, or under the auspices of an omniscient providence, they all work together to their mutual advantage, for the common weal, and in the common interest."

${ }^{15}$ Nordenstreng and Varis $(1974,54)$ noted in the conclusion of their influential report for UNESCO, which focused on the international flows of television programme and was entitled Television traffic - a one way street?, that Western exporters (unlike other exporters around the world) were able to reach across the globe with their programmes. "Consequently, exports of TV programmes to other countries seem to be associated with the wealth and size of a country" (Nordenstreng and Varis 1974, 54), they pointed out. This also meant that "the free flow of TV material between nations means in actual fact that only those countries with considerable economic resources have taken advantage of the freedom to produce, while those with scarce resources have the 'freedom' to choose whether or not to take advantage of the material made available to them" (Nordenstreng and Varis 1974, 54). Empirical results of the analysis done by Nordenstreng and Varis led to a conclusion that television traffic indeed was a one way street at the time. As a consequence, there was no need for question marks anymore: "there is no need - in fact, no justification - for a question mark after the title of this publication. Globally speaking, television traffic does flow between nations according to the 'one way street' principle: the streams of heavy traffic flow one way only" (Nordenstreng and Varis 1974, 52). Mowlana $(1985,27)$ came to similar conclusions in his report in the 1980s, which synthesized previous analyses done for UNESCO in the field of media, culture, and communications. He pointed out there is an obvious vertical flow of international news from the most developed countries to the rest of the world. While horizontal flows existed, they represented only a fraction of the entire flow of information. This pattern was repeated in all other forms of information: "With virtually all types of information flow, whether it is news or data, educational, scientific or human flow, the pattern is the same. The cycles are quite similar to cycles in other trade areas: industrially less developed countries export raw materials to highly industrialized countries for processing and then purchase back the more costly finished products. Notably lacking is the exchange of data, news, information, cultural programmes and products, and persons among developing coun-
} tries" (Mowlana 1985, 64). 
funding went directly to the military establishment. As indicated by Mosco (1982, 49-51), the US budget for telecommunications in 1982 that went directly to the Pentagon was US $\$ 14.5 \mathrm{bn}$, which was about the same as the revenue from all the radio and TV stations in the US that year. Mosco saw the Pentagon as "a major force for capital accumulation" that "exerts a substantial influence on the shape of the electronics industry" (Mosco 1982, 49, $50)$. Herbert Schiller $(2000,53)$ was certain that the rapid development of computers and other new technologies, information industries and the underlying infrastructure of the information age would never have happened without vast amounts of government money. His estimate of the subsidies and outlays for state-funded research and development in this field since the Second World War was over US\$1 trin (Schiller 2000, 53).

The last two areas of political interventionism that Dan Schiller mentions are closely connected to the proliferation of IPRs, which since the 1980s, and especially from the 1990s onward, played a very important part in the new capitalist enclosures and the rise of the socalled digital/informational capitalism (Thussu 2005, 52-54; 2006, chapter 3; D. Schiller 1999). IPRs were embedded in supranational free-trade agreements, such as the General Agreement on Trade in Services (GATS), which made possible a global harmonization of private ownership of information and imposed this onto national legislatures (cf. Marshall and Frith 2004). The long-time present American interests became a part of the World Trade Organization (WTO), which saw the free flow of information doctrine as essential for capitalist expansion (see H. Schiller 2000, 41-44; Thussu 2005, 53). "With its growing commodification, information acquired the status of a 'key strategic resource' in the international economy", Thussu (2005, 54; cf. also Berry 2008) pointed out. Consequently "its distribution, regulation, marketing and management became increasingly important" (Thussu 2005, 54).

As pointed out above, the rise of new ICTs and commodification of the wider field of communication should not, therefore, be seen as an inevitable consequence of the continuing expansion of global capitalism, neither were they an outcome of the infamous (supposedly neutral and somehow benign) transformation towards the post-industrial/information society. They can only be seen as a long-term development, which was excessively accelerated through politically orchestrated interventions since the middle of the twentieth century: on the one hand through the global expansion of new ICTs that were actively promoted by the US with huge financial investments and international policymaking, and, on the other hand, through the transnational agreements that globally deployed IPRs and promotion of the free flow of information doctrine (where information was comprehended as a commodity), which helped globally to expand communication and cultural conglomerates.

The fact there was indeed nothing unavoidable in this transformation was perhaps best exemplified by the oppositional attempts of the actors within the international movement for the New World Information and Communication Order (NWICO). This geopolitical initiative, which ran under the patronage of the Non-Aligned Movement (NAM) and UNESCO, criticized the increasing global information inequalities and further commodification of culture, information, and communication. It vigorously attempted to provide an alternative developmental pattern in this field by promoting a more just international order, albeit with little actual political success. ${ }^{16}$ It nevertheless successfully brought these issues to the fore in international decision-making arenas and explicitly called into question unequal communication and information flows by providing a critique of the structural causes for their emergence. Its proponents connected these cultural inequalities, which were often labelled under the term cultural imperialism, to the wider economic dominance present in world-wide capitalism. According to Nordenstreg $(1993,258)$, the issue of class inequalities and antagonisms was present in NWICO from its start, and for the first time in the international community, voice was given

\footnotetext{
${ }^{16}$ For a detailed account of NWICO see Herbert Schiller (1976; 1978b; 1984, ch.4), Maxwell (2003, 39-40), Nordenstreng (1993; 2013), Osolnik (2005), Thussu (2005; 2006, 24-37), Mosco (2009, 72-75), and Mattelart (2011). NWICO was a part of a wider initiative for a New International Economic Order (NIEO) promoted by countries that formed NAM (see H. Schiller 1978b, 36-38; Nordenstreng 1993, 268). It promoted the right to communicate in opposition to the free flow of information doctrine. It intellectually culminated in the MacBride report entitled Many Voices, One World, which was released under the patronage of UNESCO in 1980 (see also the special issue of journal Javnost - the Public, vol. 12, no. 3; e.g. Osolnik 2005; Thussu 2005).
} 
to those actors that were rarely heard before. An important influence on the initiative also came from the civil society and critical media and communication scholars (Nordenstreng 2013). An alternative to the exploitative and unequal international order based on structural dependencies was suggested by the MacBride commission, which promoted innovative proposals to democratize communications via the right to being informed, the right to communicate, a conceptualization of the freedom of the press, and so on (Osolnik 2005). A novel understanding of these concepts was only partly based on their traditional definitions, which often reduced those rights to an abstract and individual level (which in a capitalist society ultimately means a freedom to run a business, to paraphrase Marx) but instead connected them to certain concrete rights, for example a right to have an access to the means of mass communication, and to the wider social-economic and cultural rights. Even though NWICO was ultimately unsuccessful, its findings and proposals remain of crucial importance to this day.

\section{The Second Enclosure Movement: “...and all that is solid melts into a com- modity"?}

"In capitalism, that is to say, all that is solid melts into $P R$, and late capitalism is defined at least as much by this ubiquitous tendency towards PRproduction as it is by the imposition of market mechanisms." Mark Fisher $(2009,44)$

The vast expansion and intensification of commodification, which has developed through recent decades, opened up new possibilities for the extraction of profit from everyday activities and the new forms of labour. However, it seems that a full-blown commodification of communication, information, culture, creativity, innovation, knowledge, research and science, everyday activities, and even human affects - to name just a few - produced a novel way of carrying out commodification. A subjugation of the wider field of communication, which has been commodified in the latest wave of historical enclosures, must be separated from the things and areas that were produced and exchanged on the market earlier.

Communication and information are peculiar commodities. The basic characteristics of information and communication, after all, make them non-excludable and non-rivalrous public goods, which could even be defined as meta-public goods, because they can become more valuable when used (Perelman 2003a). This is the sole reason why they have to be enclosed through political intervention (IPRs), as, otherwise, they could not be sold as commodities. In May's $(2010,12)$ view, commodification in these cases is therefore directly linked to (new) enclosures.

Enclosures and privatization in the areas that were once a part of the public domain and constituted the society's commons (see H. Schiller 1984; 1989) was what James Boyle (2008, ch.3) called "enclosing the commons of the mind". He defined this as the second enclosure movement, which, in a very similar manner to the earlier enclosures of the commons centuries earlier, has had extra-economic incentives. The key difference is that these enclosures are now also aimed against information and cultural resources (cf. Bollier 2002; Hesmondhalgh 2008; Berry 2008; May 2010). The width of the enclosures is exemplified by Perelman $(2002,5)$, who is certain that IPRs "have contributed to one of the most massive redistributions of wealth that has ever occurred". Several authors wrote about new imperial and colonial practices (see Bettig 1996; Bollier 2002; Perelman 2002; Berry 2008, 49, 92), while Harvey $(2003,144-152 ; 2009,67-70,73-74)$ conceptualized these processes of privatization under the term accumulation by dispossession, which he used to demonstrate that primary (primitive) accumulation is a recurrent process of an often violent incorporation of different spheres into a capitalist accumulation cycle. Primary accumulation is, for Harvey, a process that does not take place only with the emergence of capitalism, but also when the system is already in place (cf. Perelman 2000). It denotes "predatory accumulation practices" that are typical of neoliberal order and commodification of divergent types of commons. This also includes, amongst others, people's histories, culture and cultural heritage, personal and 
intellectual creativity, genetic materials and so on (especially via patents and IPRs) (see Harvey 2003, 147-148; 2009, 68-69). In Berry's $(2008,53)$ view "the rapid enclosure of ideas and expressions that has intensified in the past decade" could even be labelled as "new feudalism", because it can lead to the emergence of a rentier class.

Hesmondhalgh (2008; cf. D. Schiller 2007, 43) was one of the authors that systematically applied Harvey's concept to the IPRs system, which made possible to own creativity and knowledge, bringing about a new type of imperialism. According to him "capital has shown an unprecedented interest in culture" (Hesmondhalgh 2008, 101) in the last decades, and strong IPRs were a key dimension of neoliberalism that made commodification of this sphere possible. As McChesney (2013, 80, emphasis by author) recently pointed out, copyright "protects corporate monopoly rights over culture and provides much of the profits to media conglomerates. They could not exist without it. Copyright has become a major policy encouraging the wholesale privatization of our common culture".

These new enclosures in the field of information, communication, culture, and creativity should not be taken lightly. These are the spheres of social life that are crucial for how we, as human beings, think, comprehend, normalize, reflect, rationalize, institutionalize, research, create, consolidate, question, preserve, and critically deal with our society, with its political and economic order, and, consequently, with our lives. Their commodification, therefore, has a direct influence on the quality of democracy, democratic participation and the public sphere in our society.

In a capitalist social context, anything can be commodified and subjected to the particular interests of accumulation and profitability. This is the only possible underlying goal of capital in the production and exchange of commodities. Exchange value predominates in this relationship and universal equivalence and instrumental rationality are preliminary conditions of the commodity form. Even declaratively, the central goal of these tendencies can hardly be the benefit of human beings and the promotion of democracy. Just to take an example, even the commodification of information today creates new social and economic inequalities and deepens existing ones, often influencing whole societies and communities, not "only" individuals (see H. Schiller 1996; Bettig 1996). And because IPRs can cover almost anything (Perelman 2002), especially with the help of new ICTs, everything can also be commodified, a fact that has important repercussions for wider society. This was already noticed by Jameson $(1991,37)$, when he observed that ICTs "are themselves but a distorted figuration of something even deeper, namely, the whole world system of a present-day multinational capitalism". He saw the communication network as being closely connected to capital and the global capitalist system. In this way, the commodification of communication and the seeming openness of the Internet are a perfect reflection of neo-liberal values, in which everything must be run as a business and the market should have the final word about everything (cf. Fisher 2010).

These early observations by Jameson are very close to those by Dan Schiller (2000), who closely connected computer networks to the rise of neo-liberal capitalism and the continuing global expansion of the capitalist marketplace. He used the notion of digital capitalism to denote the fact that the Internet is now one of the focal communications points of the supranational market system. It is its underlying and unavoidable infrastructure, which makes possible information sharing within and among transnational corporations. These findings should not come as a surprise, in Mattelart's $(2000,77)$ opinion communication must be omnipresent and offer completely free interaction if transnational corporations want to function properly. Otherwise the spatially separated and mutually dependent parts of the "network-firm" (its strategy is necessarily both global and local at the same time) cannot serve the whole. "Any shortcoming in the interoperability between the parts, any lack of free interaction, is a threat to the system", he points out (Mattelart 2000, 77).

It is exactly demands of the corporate business that were crucial for the development of the Internet, which made possible digital commerce. Dan Schiller's (2000, xvi) statement that "cyberspace not only exemplifies but today actually shapes the greater political economy of which it has become a critical part", in many ways underlines Jameson's earlier observations and supports them with a clear materialist historical account. Eran Fisher (2010) provided a 
similar account when he pointed out that digital discourse follows the same logic as neoliberalism and is in fact essential in comprehending society as market. Mosco (2004, 156-157) was one of the first authors to directly connect digitalization to commodification. In his opinion the emergence of cyberspace should in fact be seen in light of commodification of the whole communication process. Communication and technology help to support the expansion of commodification throughout society according to Mosco $(2009,12-13,13)$, and this has become especially manifest with the emergence of digitalization.

An important aspect of communication is its lack of solid boundaries. Communication is more often a fluid process, rather than a constant and solidified thing. This fact is perfectly encompassed in the term information flow. Communication is a constant flow that can seep through and gradually break down anything solid. Authors writing in critical communication studies learnt about this the hard way, through observing practices of cultural imperialism, as formally sovereign states had enormous difficulties constructing anything resembling impenetrable boundaries against the international communication flows organized by capital. According to Terranova $(2004,2,8)$, it is in fact difficult to think about cultural formations as completely separate entities, the key reason being the mutual and interacting connection of communication processes. This is not necessarily down to a technological interconnectedness, which is enabled by new communication channels and ICTs, but to the "nature" of the informational flows that spill over networks and circulate beyond them, constituting an informational milieu. Marazzi (2008), similarly, writes that economic relations trickle into every pore of the flexible post-Fordist society. They are now pervasive and absolutizing, and according to Marazzi (2008 43), this reflects the fact that language is similarly pervasive. ${ }^{17}$

Already at the end of the 1980s Robins and Webster (1988) paid attention to the penetration of commodification into all (even the most intimate) parts of human lives, which included the sphere of reproduction and of (formally) "free time". Mosco (1982, ch. 4, cf. Martin 2002; Wittel 2013, 315-316) similarly pointed out at that time that capital entered the sphere of intimate human relations. Also in the 1980s, Gorz (1982) noted that with the expansion of capital into "free time" profits could now also be extracted from those human activities that were previously left to human imagination. Mosco $(1989,26)$ separated between extensive and intensive commodification when he wrote about expansion of commodification to the areas that were previously outside capitalist markets. If extensive commodification denoted its extension from local to global markets, the key characteristics of intensive commodification meant that the commodity-form has now also expanded into the field of social reproduction: into home, school, entertainment and so on. There has been an obvious increase in both types of commodification, leading to till then unprecedented levels of market penetration. Because he saw commodification and new enclosures (mainly of information) as the key forces leading to social transformations at the time, Mosco (1989) would write about "the Pay-Per Society" rather than about "the information society".

\section{A Seeping Commodification}

"The total absorption in commercial translations that permeates the tightest echelons of the social order filters down to all levels." Herbert I. Schiller $(2000,45)$

Overwhelming communicative enclosures and both intensive and extensive commodification of these fields lead us to the final observation of this paper, namely, that we have been witnessing a qualitative transformation in the way commodification continues to expand. The key reason for this qualitative transformation seems to be in the characteristics of communication itself, which has been incorporated into capitalist accumulation process in all its phas-

\footnotetext{
17 In fact, language has become central in the production and exchange of things in the current phase of capitalist accumulation; communication is now both a raw material and an instrument of work according to Marazzi (2008, 49). We could thus write about semio-capital, because of "the semioticization of the social relations of production. The private has become public, and the public has become economic" (Marazzi 2008, 44).
} 
es. Communication inevitably runs throughout all the spheres of society, which is especially true with the new ICTs and concurrent expansion of digital networks that are able to permeate the most insignificant micro-practices of our lives. It would, therefore, seem reasonable to assess critically the often techno-deterministic, decontextualized and dehistoricised concept of the mediatisation of society, which nevertheless aptly illustrates the increasing communicative interconnectedness of basically every sphere of social life.

Mediatisation is a concept that has mostly been used in an affirmative and non-critical manner. There has been a few notable exceptions to this main strand of administrative scholarship dealing with mediatisation. Critical accounts include authors such as Dahlgren (2009) and Habermas (2009). Dahlgren $(2009,35)$, for example, mentions "we are awash in media", but adds they are not civic-oriented and mostly comprise of entertainment and advertising. Super-saturation and media abundance often offer more of the same, while "the media industries are following the general patterns found in the economy. Massive media empires have emerged on a global scale, concentrating ownership in the hands of a decreasing number of megacorporations" (Dahlgren 2009, 36). Dahlgren (2009, 20-21) also notes there has been an intensification of uncivic economism (mainly because of neoliberal initiatives), which is spreading market principles into noneconomic areas. In his account, this poses serious threats to democracy. He sees these processes as a "systematic ideological reconfiguration that legitimizes the private at the expense of the public" (Dahlgren 2009, 21).

Habermas (2009), likewise, writes about mediatization and media society in one of his recent texts. He puts both concepts in the context of political communication and public sphere by contrasting ideals of deliberative democracy to the (not so favourable) social reality, where power asymmetries provide sobering facts "of the ever-widening gap between normative and empirical approaches towards politics" (Dahlgren 2009, 138). While trying to remain an optimist regarding his deliberative model of democracy, Habermas $(2009,156)$ cannot but notice how mass communication turns citizens "into more or less passive spectators and consumers" and how mediatized politics has a tendency of becoming increasingly populist (Habermas 2009, 157). Media-based communication meanwhile remains a domain, which is dominated especially by communication of elites, he stresses (Habermas 2009, 161, 165). $\mathrm{He}$ is also adamant that economic power remains "the dominant form in capitalist societies" (Habermas 2009, 168) and that media owners can "use their economic power to convert media power directly into public influence" (Habermas 2009, 176). Furthermore, Habermas $(2009,175)$ points out one can often find inability within media organizations to distance themselves "from associations and organizations representing economic or other special interests" and adds that the public sphere has been colonized by market imperatives (Habermas 2009, 177).

These two cases of critical scholarship dealing with mediatization, however, seem exceptions to the rule. Moreover, it must be remarked that neither Dahlgren nor Habermas have attempted to provide any overarching theoretical accounts of mediatization. They understood this concept as a relatively insignificant part of their critical writings on public sphere. In contrast to their accounts, theories of mediatization mostly ignore this wider social context that brings about vast asymmetries and inequalities. It is often presupposed in these theories that there is an intrinsic capacity within the media to produce certain outcomes, while communication systems and media technologies are somehow autonomous in their historical development and detached from wider social relations ${ }^{18}$. Authors writing on mediatization often deterministically focus on technology, which supposedly brings about changes, sometimes even in a completely causal manner. They only rarely take into account embeddedness of media into the existing power structures, provide wider contextual reasons for their emergence and consolidation, or main causes for their expansion (cf. Fuchs 2014, 55-57). When writing about technology and its use, such authors consequently abstract from both the historical relations of power and the existing political-economic context, namely capitalism.

\footnotetext{
${ }^{18}$ For a materialist critique of such approaches see Williams (1974/2003, ch.1). In them, technology is often described as a cause, but in the mysterious abstract terms of technology as such. It is therefore not a concrete technology, which is owned by a multinational corporation in a capitalist society, where the main intention is profitmaking, but something that could as such help to shift power relations away from politics and economic elites.
} 
Indeed, in some cases, technology is in fact causally identified as the reason of social change in these theories, instead of being embedded and produced within a certain historical social totality. In one of the most cited articles on mediatization, Hjarvard (2008) for example notes how society is permeated by the media. According to him, media thus became omnipresent and operate with a logic that is completely their own. He claims we cannot conceive media as being separated from cultural and social institutions as in the past and even advocates a holistic approach to them. But instead of following to his promise of holism, he separates the operation of media and the main reasons for their omnipresence from the social and political-economic order. It seems as if it is completely unimportant in what structural setting technological innovations emerge or how media in fact operate: whether they are owned by a capitalist corporation; or if they are used for a more effective world-wide corporate and market communication; if their research and development have been financed through military-industrial-communication complex; if they have been developed with a more or less clear intention for more effective operation of (and on) the markets; or if they are used by political activists, with an aim to build common social spaces and resources that can be used as tools of class struggle. In mediatization theories, such as Hjarvard's (2008), it is media as such - as if they are autonomous actors - that exert influence. It is not institutions that own and control them, people that work within and with them, or social relations which influence their development and how they are bound to operate.

Another example of a theory of mediatization is provided by Livingstone (2009). While Livingstone does not assign such a causal role for social changes to technology like Hjarvard does, she nevertheless fails to embed the process of mediation/mediatization within capitalism or an often violent incorporation of communications into capitalist market ${ }^{19}$. Livingstone thus abstracts "only" from the political-economic base. Because of that, she is confronted with significant difficulties when she attempts to provide a serious analysis of who is benefitting from such a social order (see Livingstone 2009, 11). Surely we are not living in a world where the benefits are spread equally and mediatization is some neutral or even natural phenomena that emerged out of social vacuum?

Theories of mediatization have too often proved to be ignorant to the political-economic context within which media are embedded. As it is becoming increasingly evident, however, we are in fact living in a media saturated world and with the impending coming of "the internet of things" this total connectedness is only set to further increase. Subjecting the concept of mediatization to a historical-materialist analysis would therefore seem inevitable for its proper understanding. Seeing this concept in the context of the political economy of communication advocated throughout this text, we are bound to recognize in it, to use the words of Debord (1970, paragraph 35), "our old enemy, the commodity". To put it differently: when capital fully encloses the wider field of communication, mediatization in communicative capitalism can be seen only for what it is: a continuing commodification of our everyday life. The digitalization of media and the subsequent total mediatization of our society has, after all, helped to further spread the Debordian spectacle and intensified its presence in postmodern societies. Let us not forget that, according to Debord (1970, paragraph 42), "The spectacle is the moment when the commodity has attained the total occupation of social life. The relation to the commodity is not only visible, but one no longer sees anything but it".

Some very similar characteristics that hold for communication can therefore be attributed to commodification when it fully encroaches upon information, communication, and culture (including their production, distribution, and consumption). Murdock $(2014,140)$ recently came to a similar conclusion in his critique of the celebratory observers of digital technologies. According to him, such non-critical authors "are apt to forget that this increasing mediatization of everyday life is not an abstract movement. It is part of a generalised, and very concrete, process of intensified integration into commodity culture".

\footnotetext{
19 In one of the footnotes, Livingstone $(2009,14)$ writes "it could be hardly claimed that mediation theorists are unconcerned with the power inequalities that differentially constrain or enable people's actions", but only one reference she provides actually speaks volumes on how frequently such occurrences are in those theories.
} 
What some authors uncritically define as mediatization, must therefore, at least in my opinion, first and foremost be seen in the context of a wide-spread intensification and expansion of the commodification process to the spheres, processes, things, relations, and resources that were formerly based outside of the market. The expansion of communication networks and digitalization have provided an important infrastructure that helped both to extend and intensify commodification throughout places that have hitherto been untouched by capitalist market.

On this basis, it is possible to propose a concept of a seeping commodification, a qualitatively novel type of the commodification process. The key characteristic of a seeping commodification is the fact that, in the current historical epoch, commodity form is able to trickle down to all the niches and activities of society and human lives. A seeping commodification is able to more or less successfully mimic the activities that are distinctive of communication, which has (in the recent decades) been completely absorbed into the capitalist accumulation circuit.

Because of these characteristics, commodification is nowadays able literally to seep into the spheres that seemed completely impenetrable (even unimaginable) to the market exchange in the past. For example, one only needs to think of the importance of the (commodified) genome in the rise of biotechnology (Rifkin 1999) or the statistical collections of personal data, which presuppose novel and intrusive forms of (amongst other types especially economic) surveillance with the new ICTs (see Allmer 2012; Fuchs et al 2011; Sandoval 2011). Or let us consider the increasing intrusiveness of the corporate branding, which now also covers branding of nations (see Kania-Lundholm 2012, ch.3), whole communities (Prodnik $2012 b$ ), or even faculty departments at universities. One of the most absurd cases of the latter is provided by the IEDC-Bled School of Management (Slovenia), which today includes The Coca-Cola Chair of Sustainable Development ${ }^{20}$. No less absurd are Amazon's patent on the single-click buying method (see Berry 2008, 34), U.S. Olympic Committee's trademark over the word "Olympic" (see Boyle 2008, xi-xii), Microsoft's double-clicking patent ${ }^{21}$, or copyright claim over football match fixtures in the English Premier League, which lasted for a few years and has later been removed by the European Court of Justice.

One of the consequences of the process of a seeping commodification is that many boundaries are starting to disintegrate before our eyes, leaving the door open for further expansion of capital. It is not only that communication and information do not pay regard to any solid boundaries; they also became a constituent part of almost every institution, process, and thing in society, including a crucial part of the (post-Fordist) production process (Marazzi 2008). It is significant that an important characteristic of postmodernity is, precisely, fluidity. Bauman (2000), for example, used a very suitable metaphor of "the liquid modernity" to demonstrate that society on the one hand has remained the same (modern capitalism) and, on the other hand, that there are constant changes occurring throughout society (liquidity): this is the persisting continuity and change, which is occurring simultaneously, and has been mentioned earlier in the text. The liquidity of communication is accompanied by a strict rigidity, which is required by commodity form, market exchange, and capitalist social relations.

Since communication is now an integral part of all aspects of human lives, commodification can spill across all society and quietly seep into formerly intact areas and relations. This constant problem of setting boundaries and limitations was closely observed by Dan Schiller (2007, 24-27). He stressed it has become near-impossible for communication scholars to focus only on the narrow field of media under informationalized digital capitalism. The areas that have traditionally been of interest to the media and communication research have now started to overlap with other spheres, such as the (increasingly commodified) field of biotechnology.

The transition to information capitalism does not depend on or equate with a narrow sector of media-based products. It is coextensive with a socio-economic met-

\footnotetext{
${ }^{20}$ See: http://www.iedc.si/about-iedc/history (1. 2. 2014).

21 See: http://www.wired.com/techbiz/media/news/2004/06/63707 (1. 2. 2014).
} 
amorphosis of information across a great (and still-undetermined) range. As commodity relations are imposed on previously overlooked spheres of production, new forms of genetic and biochemical information acquire an unanticipated equivalence with other, more familiar genres (D. Schiller 2007, 25).

As mentioned, an important epiphenomenon of these processes is a continuous disintegration of many boundaries and their transformation into indefinable, malleable and constantly changeable areas and processes (cf. Deleuze 1992). There has, for example, been a disintegration of the dividing line between the spheres of the intimate, the private and the public, and of the formerly clearer distinctions between journalism and PR (see Dahlgren 2009, 49). Public communication and advertisement have, likewise, started to merge, while the dichotomy between the virtual and the real is falling apart and becoming more and more irrelevant (see Prodnik 2012b). One could also point to the formerly strict separation lines between the sovereign nation states and the wider global order that now dissipated because of the disintegration of the national borders for capital flows ${ }^{22}$. Similarly, separation between public and private ownership has started disintegrate both in the form of public-private ownerships and in recent socializations of private debts. There has also been an incorporation of our most intimate information into the circuit of capital via digital surveillance, which makes possible new types of quantification and amassment of data (the so-called "big data") that via economic surveillance lead to commodification of personal characteristics of the internet users and their everyday life activities (see Allmer 2012; Fuchs et al 2011; Sandoval 2011). The same disintegrative process, as already mentioned, is happening between the formerly very distinct spheres of production and reproduction, or between leisure time and work time (Gorz 2010; Prodnik 2012a). While none of these boundaries were ever impenetrable and their slow disintegration is evident for several decades now, they are becoming increasingly porous and vague as somehow clear demarcation lines.

Herbert Schiller (1989) already noticed these changes decades ago, when he pointed out how different spheres and parts of society have started to blur. Amongst the key reasons for this transformation was an offensive of the corporate capital, which started to permeate all social spaces. Furthermore, "deregulation, privatization, and the expansion of market relationships have affected all corners of the economy" (H. Schiller 1996, 46).

What seems of prime importance is not only that commodification has encompassed new spheres of social life, but that even the spheres that are not (or, at least not yet) subjugated to these tendencies, are being remodelled in the ways to reflect the rules of the capitalist market. Even the projects and activities not driven directly by market considerations are now compelled to justify their existence through neoliberal categories such as efficiency, the real "use-value" of some public project (which is in fact the exchange-value on and for the market), economistic rationale and so on. This is the instrumentalized quantifying logic that is distinctive of neoliberal capitalism, where the legitimation for doing something must be either directly - or at the very least indirectly - connected to the underlying logic distinctive of the capitalist market.

With a general commodification of communication, there is an emergence of several new dilemmas, contradictions, conflicts, and antagonistic relations - from the rise in rent capitalism to the new forms of labour and the ways in which value is created. These contradictions perhaps indicate a fundamental structural crisis of capitalism, which could be transforming into a new phase of its development. There seems to be no doubt, as Wallerstein $(1991 / 2001,167)$ warns that "[t]he bourgeoisie of today are already in the process of trying to survive their structural crisis by transforming themselves into ' $x$ ' reigning over a new mode of production". This takeover, however, is neither inevitable nor completely unstoppable. The multifacetedness and contradictory nature of these intrusive social processes lies primarily in the fact that singularities and political subjectivities - such as alternative social movements -

\footnotetext{
${ }^{22}$ Herbert Schiller $(1996,113,114)$ pointed out it was already satellite technology that "has largely made national borders irrelevant." In his view "global corporations and media-cultural conglomerates [...] are indifferent to formal communication boundaries."
} 
are struggling to create common spaces of living and acting that oppose total capitalist colonization (e.g. Negri and Hardt 2009).

The lessons of the past teach us that the bulldozing power of capital should not be naively underestimated, as the seemingly unstoppable expansion of capitalism marches forward, rarely being systematically opposed. But, even though there is a tendency to commodify everything, capital can never subjugate all social spheres. It cannot colonize human languagecapacity, which makes possible creativity and virtuosity, even if it can commodify everything that originates in, and results from, communication. With its expansion into all spheres and areas commodification also "moves inexorably toward an asymptote of 100 percent. Once we are in the upper ranges of this curve, each further step begins to put a squeeze on global profit and hence renders very acute the internal competition among the accumulators of capital" (Wallerstein 1991/2001, 24-25). This leads to the limits of growth, to economic crisis, and consequently to new political turmoil, when alternatives to the present social order seem more pressing and feasible.

Even though there has been a more or less successful capitalist colonisation of many areas that have so far not been subordinated to the reign of the commodity form, it should be noted that a seeping commodification is not an unequivocal process; it is, rather, a very ambivalent and contradictory one, in large part owing exactly to its mutability and lack of boundaries. Conflicts and contradictions can emerge at all levels of social reality and what seems like an opportunity for capital, can quite often be subverted against it. Holloway (2010) metaphorically wrote about "crack capitalism" as a way of radically transforming the world. In Holloway's new grammar of revolution, cracks are spaces that defy logic of capitalism and produce oppositional social relations. They are often simple and small acts of rebellion that produce small ruptures to the dominant dynamic of social totality, which attempt to turn these processes in the opposite way.

Communication can both be commodified and, at the same time, be a tool against oppression; its liquidity and lack of boundaries may be both a liability and an opportunity. Similarly, digital sphere is extremely commodified, but also offers rejection of capitalist social relations and offers new spaces of oppositional practices. Political movements are establishing active forms of rebellion, and there are both theoretic alternatives and practical applications that go beyond capitalist organization of communication, culture, and information. Together with these alternatives, new forms and possibilities for organization emerge. Williams (1980/2005, 33-35) forcefully argued that contradictions are not present only at the level of super-structure, where there are ideological conflicts are being played out. They are also present at the level of political-economic base, where capitalist relations of production are currently dominant, but are also opposed with alternative organization of production. Base in a concrete historical context should therefore not be seen as uniform or static; on the contrary, it is dynamic and contradictory. This means that alternative relations of production can both emerge or already be present within the wider capitalist context. Such antagonist struggles are best exemplified by movements that fight for (the/a) common(s). They present one possible alternative vision of the future that counters commodification, goes against capitalism and beyond public/private dichotomy (see Mosco 1989, 24; Bollier 2002; Dyer-Witheford 2007; Berry 2008; Negri and Hardt 2009; Murdock 2011; Wittel 2013). To put it in the words of Dyer-Witheford $(2007,28)$ : "If the cell form of capitalism is the commodity, the cellular form of a society beyond capital is the common".

\section{References}

Allmer, Thomas. 2012. Towards a Critical Theory of Surveillance in Informational Capitalism. Frankfurt am Main: Peter Lang.

Arrighi, Giovanni. 1994. The Long Twentieth Century: Money, Power, and the Origins of Our Times. London, New York: Verso.

Baker, Edwin C. 1994. Advertising and a Democratic Press. Princeton, New Jersey: Princeton University Press.

Barbalet, Jack M. 1983. Marx's Construction of Social Theory. London: Routledge and Keegan Paul.

Bauman, Zygmunt. 2000. Liquid Modernity. Cambridge, Malden: Polity. 
Berry, David. 2008. Copy, Rip, Burn: The Politics of Copyleft and Open Source. London: Pluto Press.

Bettig, Ronald V. 1996. Copyright Culture: The Political Economy of Intellectual Property. Boulder: Westview Press.

Bonefeld, Werner. 2009. Emancipatory Praxis and Conceptuality in Adorno. In Negativity and Revolution: Adorno and Political Activism, eds. John Holloway, Fernando Matamoros and Sergio Tischler, 122-150. London: Pluto Press.

Bollier, David. 2002. Silent Theft: The Private Plunder of Our Common Wealth. New York, London: Routledge.

Boyle, James. 2008. The Public Domain: Enclosing the Commons of the Mind. New Haven, London: Yale University Press.

Braudel, Fernand. 1980. History and the Social Sciences: The Longue Durée. In On History, 25-54. Chicago: Chicago University Press.

Braudel, Fernand. Afterthoughts on Material Civilization and Capitalism. Baltimore, MD: The John Hopkins University Press.

Bücher, Carl Wilhelm. 1893/1901. Industrial Evolution. New York: Henry Holt.

Crary, Jonathan. 2013. 24/7: Late Capitalism and the Ends of Sleep. London: Verso.

Curran, James. 2002. Media and Power. London: Routledge.

Debord, Guy. 1970. Society of Spectacle. Detroit: Black and Red Press.

Deleuze, Gilles. 1992. Postscript on the Societies of Control. October 59: 3-7.

Doogan, Kevin. 2009. New Capitalism? The Transformation of Work. Cambridge, Malden: Polity Press.

Douglas, Sarah and Thomas Guback. 1984. Production and Technology in the Communication/Information Revolution. Media, Culture \& Society 6 (3): 233-245.

Dupuy, Jean-Pierre. 1980. Myths of the Informational Society. In The Myths of Information: Technology and Postindustrial Culture, ed. Kathleen Woodward, 3-17. Madison: Coda Press.

Dyer-Witheford, Nick. 1999. Cyber-Marx: Cycles and Circuits in High Technology Capitalism. Urbana: University of Illinois Press.

Dyer-Witheford, Nick. 2007. Commonism. Turbulence 1 (1): 28-29.

Fisher, Eran. 2010. Media and New Capitalism in the Digital Age: The Spirit of Networks. New York: Palgrave Macmillan.

Fisher, Mark. 2009. Capitalist Realism: Is There no Alternative? Winchester: Zero Books.

Frith, Simon and Lee Marshal, eds. 2004. Music and Copyright. New York: Routledge.

Fuchs, Christian. 2008. Internet and Society: Social Theory in the Information Age. New York: Routledge.

Fuchs, Christian. 2011. Foundations of Critical Media and Information Studies. London: Routledge.

Fuchs, Christian. 2012a. Dallas Smythe Today - The Audience Commodity, the Digital Labour Debate, Marxist Political Economy and Critical Theory. Prolegomena to a Digital Labour Theory of Value. TripleC: Communication, Capitalism \& Critique 10(2): 692-740.

Fuchs, Christian. 2012b. Capitalism or Information Society? The Fundamental Question of the Present Structure of Society. European Journal of Social Theory 16 (4): 1-22.

Fuchs, Christian, Kees Boersma, Anders Albrechtslund and Marisol Sandoval, eds. 2011. Internet and Surveillance: The Challenges of Web 2.0 and Social Media. New York: Routledge.

Fuchs, Christian and Sebastian Sevignani. What is Digital Labour? What is Digital Work? What's their Difference? And why do These Questions Matter for Understanding Social Media? TripleC: Communication, Capitalism \& Critique 11 (2): 237-293

Fuchs, Christian. 2014. Critique of the Political Economy of Informational Capitalism and Social Media. In Critique, Social Media and the Information Society, eds. Christian Fuchs and Marisol Sandoval, 51-65. New York, Oxon: Routledge.

Gandy, Oscar H. Jr. 1992. The Political Economy Approach: A Critical Challenge. Journal of Media Economics 5 (2): 23-42.

Gorz. André. 2010. The Immaterial. London: Seagull Books.

Habermas, Jürgen. 2009. Political Communication in Media Society: Does Democracy Still Have an Epistemic Dimension? In Europe: The Faltering Project, 138-183. Cambridge, Malden: Polity Press.

Hardt, Hanno. 1979. Social Theories of the Press: Early German and American Perspectives. Beverly Hills, CA: Sage Publications.

Hardt, Hanno. 2001. Social Theories of the Press: Constituents of Communication Research, 1840s to 1920s. 2nd edition. Lanham: Rowman \& Littlefield Publishers. 
Harvey, David. 2003. The New Imperialism. Oxford, New York: Oxford University Press.

Harvey, David. 2009. Cosmopolitanism and the Geographies of Freedom. New York: Columbia University Press.

Harvey, David. 2010. A Companion to Marx's Capital. London: Verso.

Hay, Colin. 2002. Political Analysis: A Critical Introduction. New York: Palgrave.

Headrick, Daniel R. 2000. When Information Came of Age: Technologies of Knowledge in the Age of Reason and Revolution, 1700-1850. Oxford, New York: Oxford University Press.

Heinrich, Michael. 2012. An Introduction to the Three Volumes of Karl Marx's Capital. New York: Monthly Review Press.

Hesmondhalgh, David. 2008. Neoliberalism, Imperialism and the Media. In The Media and Social Theory, eds. David Hesmondhalgh and Jason Toynbee, 95-111. Abingdon and New York: Routledge.

Hjarvard, Stig. 2008. The Mediatization of Society: A Theory of the Media as Agents of Social and Cultural Change. Nordicom Review 29 (2): 105-134.

Holloway, John. 2010. Crack Capitalism. London: Pluto Press.

Jameson, Fredric. 1991. Postmodernism, or, The Cultural Logic of Late Capitalism. Durham: Duke University Press.

Jameson, Fredric. 1998. The Cultural Turn: Selected Writings on the Postmodern, 1983-1998. London, New York: Verso.

Jameson, Fredric. 2007. Jameson on Jameson: Conversations on Cultural Marxism. Durham: Duke University Press.

Jhally, Sut. 2006. The Spectacle of Accumulation: Essays in Media, Culture \& Politics. New York: Peter Lang Publishers.

Kania-Lundholm, Magdalena. 2012. Re-Branding a Nation Online: Discourses on Polish Nationalism and Patriotism. Dissertation. Uppsala: Uppsala University.

Livant, Bill. 1979. The Audience Commodity: On the Blindspot Debate. Canadian Journal of Political and Social Theory 3 (1): 91-106.

Livingstone, Sonia. 2009. On the Mediation of Everything: ICA Presidential Address 2008. Journal of Communication 59 (1) 1-17.

Marazzi, Christian. 2008. Capital and Language: From the New Economy to the War Economy. Los Angeles, CA: Semiotext(e).

Martin, Randy. 2002. Financialization of Daily Life. Philadelphia: Temple University Press.

Marx, Karl and Frederick Engels. 1848. Manifesto of the Communist Party. Accessed July 1, 2013. http://www.marxists.org/archive/marx/works/1848/communist-manifesto/ch01.htm

Marx, Karl. 1976/1990. Capital: A Critique of Political Economy, Volume One. London: Penguin Books.

Mattelart, Armand. 2000. Networking the World, 1794-2000. Minneapolis, MA: University of Minnesota Press.

Mattelart, Armand. 2011. New International Debates on Culture, Information, and Communication. In The Handbook of Political Economy of Communications, eds. Janet Wasko, Graham Murdock and Helena Sousa, 501-520. Malden, Oxford: Wiley-Blackwell.

May, Christopher. 2002. The Information Society: A Sceptical View. Malden, Cambridge: Polity Press.

May, Christopher. 2010. The Global Political Economy of Intellectual Property Rights: The New Enclosures. 2nd edition. New York: Routledge.

Maxwell, Richard. 2003. Herbert Schiller. Lanham: Rowman and Littlefield.

McChesney, Robert W., Ellen Meiksins Wood and John Bellamy Foster, eds.. 1998. Capitalism and the Information Age: The Political Economy of the Global Communication Revolution. New York: Monthly Review Press.

McChesney, Robert W. 2013. Digital Disconnect: How Capitalism is Turning the Internet against Democracy. New York: The New Press.

Melody, William H. 1993. On the Political Economy of Communication in the Information Society. In Illuminating the Blindspots: Essays Honoring Dallas W. Smythe, eds. Janet Wasko, Vincent Mosco and Manjunath Pendakur, 63-81. Norwood, NJ: Ablex.

Mosco, Vincent. 1982. Pushbutton Fantasies: Critical Perspectives on Videotext and Information Technology. Norwood, NJ: Ablex.

Mosco, Vincent. 1989. The Pay-Per Society: Computers \& Communication in the Information Age. Toronto: Garamond Press. 
Mosco, Vincent. 1993. Free Trade in Communication: Building a World Business Order. In Beyond National Sovereignty: International Communication in the 1990s, eds. Kaarle Nordenstreng and Herbert I. Schuller, 193-209. Norwood, NJ: Ablex.

Mosco, Vincent. 2009. The Political Economy of Communication. 2nd edition. Los Angeles, London: Sage.

Mowlana, Hamid. 1985. International Flow of Information: A Global Report and Analysis. [Unesco Reports and Papers on Mass Communication, No. 99]. Paris: Unesco.

Murdock, Graham. 2006a. Marx on Commodities, Contradictions and Globalisation: Resources for a Critique of Marketised Culture. E-Compós 7: 1-23.

Murdock, Graham. 2006b. Notes from the Number One Country: Herbert Schiller on Culture, Commerce, and American Power. International Journal of Cultural Policy 12 (2): 209-227.

Murdock, Graham. 2011. Political Economies as Moral Economies: Commodities, Gifts and Public Goods. In The Handbook of Political Economy of Communications, eds. Janet Wasko, Graham Murdock and Helena Sousa, 41-62. Malden, Blackwell.

Negri, Toni and Michael Hardt. 2009. Commonwealth. Cambridge: The Belknap Press of Harvard University Press.

Nordenstreng, Kaarle. 1993. New Information Order and Communication Scholarship: Reflections on a Delicate Relationship. In Illuminating the Blindspots: Essays Honouring Dallas W. Smythe, eds. Janet Wasko, Vincent Mosco and Manjunath Pendakur, 251-273. Norwood, NJ: Ablex.

Nordenstreng, Kaarle. 2013. How the New World Order and Imperialism Challenge Media. TripleC Capitalism, Communication \& Critique 11 (2): 348-358.

Nordenstreng, Kaarle and Tapio Varis. 1974. Television Traffic - A One-Way Street? A Survey and Analysis of the international Flow of Television Programme Material. [Unesco Reports and Papers on Mass Communication, No. 70]. Paris: Unesco.

Offe, Claus. 1984. The Contradictions of the Welfare State. Cambridge, MA: The MIT Press.

Offe, Claus. 1987. Challenging the Boundaries of Institutional Politics: Social Movements since the 1960s. In Changing Boundaries of the Political, ed. Chrales S. Maier, 63-105. Cambridge: Cambridge University Press.

Osolnik, Bogdan. 2005. The MacBride Report - 25 Years Later. Javnost - The Public 12 (3): 5-12.

Park, Robert Ezra. 1922. The Immigrant Press and Its Control. New York, London: Harper \& Brothers Publishers.

Perelman, Michael. 2000. The Invention of Capitalism: Classical Political Economy and the Secret History of Primitive Accumulation. Durham: Duke University Press.

Perelman, Michael. 2002. Steal This Idea: Intellectual Property Rights and the Corporate Confiscation of Creativity. New York: Palgrave.

Perelman, Michael. 2003a. Intellectual Property Rights and the Commodity Form: New Dimensions in the Legislated Transfer of Surplus Value. Review of Radical Political Economics 35 (3): 304-311.

Perelman, Michael. 2003b. The Weakness in Strong Intellectual Property Rights. Challenge 46 (6): $32-$ 61.

Prodnik, Jernej. 2012a. A Note on the Ongoing Processes of Commodification: From the Audience Commodity to the Social Factory. TripleC: Communication, Capitalism \& (Special Issue "Marx is Back", eds. Christian Fuchs and Vincent Mosco) 10 (2): 274-301.

Prodnik, Jernej. 2012b. Post-Fordist Communities and Cyberspace: A Critical Approach. In Cybercultures: Mediations of Community, Culture, Politics, eds. Harris Breslow and Aris Mousoutzanis, 75100. Amsterdam, New York: Rodopi.

Rifkin, Jeremy. 2000. The Age of Access: The New Culture of Hypercapitalism, Where All of Life Is a Paid-for Experience. New York: Penguin.

Robins, Kevin and Frank Webster. 1988. Cybernetic Capitalism: Information, Technology, Everyday Life. In The Political Economy of Information, eds. Vincent Mosco and Janet Wasko, 44-75. Madison, WI: The University of Wisconsin Press.

Robins, Kevin and Frank Webster. 2004. The Long History of the Information Revolution. In The Information Society Reader, ed. Frank Webster, 62-80. Routledge: London.

Sandel, Michael. 2012. What Money Can't Buy: The Moral Limits of Markets. London: Allen Lane.

Sandoval, Marisol. 2011.Consumer Surveillance on Web 2.0. In Internet and Surveillance, eds. Christian Fuchs, Kees Boersma, Anders Albrechtslund and Marisol Sandoval, 147-169. New York: Routledge.

Schiller, Dan. 1999. Digital Capitalism: Networking the Global Market System. Cambridge, MA: The MIT Press. 
Schiller, Dan. 2007. How to Think about Information. Urbana, IL: University of Illinois Press.

Schiller, Herbert Irwing. 1969. Mass Communications and American Empire. Boston, MA: Beacon Press.

Schiller, Herbert Irwing. 1973. The Mind Managers. Boston, MA: Beacon Press.

Schiller, Herbert Irwing. 1976. Communication and Cultural Domination. New York: International Arts and Sciences Press.

Schiller, Herbert Irwing. 1978a. Communication Accompanies Capital Flows. [Reports and Papers on Mass Communication, No. 47]. Paris: UNESCO.

Schiller, Herbert Irwing. 1978b. Decolonization of Information: Efforts toward a New International Order. Latin American Perspectives 5 (1): 35-48.

Schiller, Herbert Irwing. 1984. Information and the Crisis Economy. Norwood, NJ: Ablex Publishing Corporation.

Schiller, Herbert Irwing. 1989. Culture, Inc. The Corporate Takeover of Public Expression. New York, Oxford: Oxford University Press.

Schiller, Herbert Irwing. 1996. Information Inequality: The Deepening Social Crisis in America. London: Routledge.

Schiller, Herbert Irwing. 1998. Striving for communication dominance: a half-century review. In Electronic Empires: Global Media and Local Resistance, ed. Daya Kishan Thussu, p17-26. London: Arnold.

Schiller, Herbert Irwing. 2000. Living in the Number One Country: Reflections from a Critic of American Empire. New York: Seven Stories Press.

Schudson, Michael. 1978. Discovering the News: A Social History of American Newspapers. New York: Basic Books.

Smythe, Dallas W. 1954. Some Observations on Communications Theory. Audio Visual Communication Review 2 (1): 24-37.

Smythe, Dallas W. 1977. Communications: Blindspot of Western Marxism. In Counterclockwise: Perspectives on Communication, ed. Thomas Guback, 266-291. Boulder, CO: Westview Press.

Splichal, Slavko.1981. Množično komuniciranje med svobodo in odtujitvijo [Mass Communication Between Freedom and Alienation]. Maribor: Obzorja.

Terranova, Tiziana. 2004. Network Culture: Politics for the Information Age. London: Pluto Press.

Thompson, Edward Palmer. 1991. Customs in Common. London: Merlin Press.

Thussu, Daya Kishan, ed. 1998. Electronic Empires: Global Media and Local Resistance. London, New York: Arnold.

Thussu, Daya Kishnan. 2005. From MacBride to Murdoch: The Marketisation of Global Communication. Javnost - The Public 12 (3): 47-60.

Thussu, Daya Kishnan. 2006. International Communication: Continuity and Change. 2nd Edition. London: Hodder Arnold.

Wallerstein, Immanuel. 1983. Historical Capitalism. London: Verso.

Wallerstein, Immanuel. 1991/2001. Unthinking Social Science: The Limits of Nineteenth-Century Paradigms. 2nd edition. Philadelphia, PA: Temple University Press

Williams, Raymond. 1962. Communications. Baltimore, MD: Penguin Books.

Williams, Raymond. 1961/2011. The Long Revolution. Cardigan: Parthian Books.

Williams, Raymond. 1974/2003. Television: Technology and Cultural Form. London: Routledge.

Williams, Raymond. 1980/2005. Culture and Materialism. London, New York: Verso.

Winseck, Dwayne R. and Robert M. Pike. 2007. Communication and Empire: Media, Markets, and Globalization, 1860-1930. Durham: Duke University Press.

Winseck, Dwayne R. 2011. The Political Economies of Media and the Transformation of the Global Media Industries. In Dwayne R. Winseck and Dal Yong Jin (eds.), The Political Economies of Media: The Transformations of the Global Media Industries, eds. Wayne R. Winseck and Dal Yong Jin, 3-48. London: Bloomsbury Academic.

Wittel, Andreas. 2013. Counter-commodification: The economy of contribution in the digital commons. Culture and Organization 19 (4): 314-331.

\section{About the Author}

Jernej Amon Prodnik

is a Researcher at the Social Communication Research Centre and a Teaching Assistant at the Media Studies department, Faculty of Social Sciences, University of Ljubljana (Slovenia). He defended his 
$\mathrm{PhD}$ in media and communication studies at the University of Ljubljana in 2013 under the title Political Economy of Communication and Structural Transformations of Capitalism. His principal research interests include critique of political economy (with a focus on media and communication), structural transformations of capitalist societies, and the wider social context of technological changes and democratic potentials brought about by new technologies. 